\title{
An inflammatory myofibroblastic tumor exhibiting immunoreactivity to KIT: a case report focusing on a diagnostic pitfall
}

Tatsuki R Kataoka ${ }^{1}$, Nobuhiro Yamashita ${ }^{2}$, Ayako Furuhata ${ }^{1}$, Masahiro Hirata', Takaki Ishida ${ }^{3}$, Ichiro Nakamura ${ }^{3}$, Seiichi Hirota ${ }^{4}$, Hironori Haga ${ }^{1 *}$ and Eiji Katsuyama ${ }^{2}$

\begin{abstract}
Inflammatory myofibroblastic tumors (IMTs) and gastrointestinal stromal tumors (GISTs) are both spindle cell tumors, and occur rarely in the wall of the urinary bladder. In general, immunostaining allows differentiation of IMTs and GISTs. Most IMTs are positive for anaplastic lymphoma kinase (ALK) and negative for KIT, whereas most GISTs are ALK-negative and KIT-positive. Here, we describe a case of a spindle cell tumor in the wall of the urinary bladder. The spindle cells were positive for both ALK and KIT, and it was thus difficult to determine whether the tumor was an IMT or a GIST. We eventually diagnosed an IMT, because ALK gene rearrangement was confirmed by fluorescent in-situ hybridization. Cytoplasmic staining for KIT and the absence of other GIST markers, including DOG1 and platelet-derived growth factor $a$, indicated that the tumor was not a GIST. Therefore, IMTs should be included in the differential diagnosis of spindle cell tumors, even those that are KIT-positive.
\end{abstract}

Keywords: Anaplastic lymphoma kinase, Differential diagnosis, FISH, Gastrointestinal stromal tumor, Inflammatory myofibroblastic tumor, KIT, Urinary bladder

\section{Background}

Inflammatory myofibroblastic tumors (IMTs) are spindle cell tumors sometimes considered to exhibit borderline malignancy [1]. These tumors are characterized by the infiltration of inflammatory cells, including lymphocytes, plasma cells, and eosinophils [1] and can occur at any site in the body, including the urinary bladder $[2,3]$. Approximately half of all IMTs exhibit anaplastic lymphoma kinase $(A L K)$ gene rearrangements [4], which are considered to be an IMT marker, as are expression of vimentin, muscle-specific actin, and calponin [5-7]. The majority of IMTs do not express S-100, KIT, or CD34 [5-7].

A gastrointestinal stromal tumor (GIST) is another form of spindle cell tumor [8] that rarely occurs in the urinary bladder $[9,10]$. Most GISTs exhibit gain-

\footnotetext{
* Correspondence: haga@kuhp.kyoto-u.ac.jp

'Department of Diagnostic Pathology, Kyoto University Hospital, Sakyo-ku, Kyoto 606-8507, Japan

Full list of author information is available at the end of the article
}

of-function mutations in the KIT gene and express KIT protein $[11,12]$. KIT is a receptor-type tyrosine kinase [13] and is thus usually present in membranes, but it may also be expressed in the cytoplasm. Some GISTs lacking KIT mutations have mutations in the platelet-derived growth factor receptor $\alpha$ (PDGFR $\alpha$ ) gene [14]. In such cases, PDGFR $\alpha$ serves as a GIST marker [14]. The DOG1 gene is also considered to be a marker of GIST [15].

Here, we describe a spindle cell tumor that developed in the wall of the urinary bladder. Immunostaining showed that the tumor cells were positive for both ALK and KIT expression, and it was thus difficult to distinguish whether the tumor was an IMT or GIST.

\section{Case presentation Methods Immunostaining}

The antibodies used are listed in Tables 1 and 2 . Cytological specimens were fixed in 100\% methanol, 
Table 1 Antibodies used for immunostaining in immunocytochemical analyses.

\begin{tabular}{lllll}
\hline Antigen & Clone & Dilution & Source & Pretreatment \\
\hline SMA & 1A4 & Prediluted & Nichirei & None \\
Desmin & D33 & Prediluted & Nichirei & None \\
Pan-cytokeratin & AE1/AE3 & Prediluted & Nichirei & None \\
KIT & Polyclonal & $1: 25$ & DAKO & None \\
ALK & SA4 & Prediluted & Nichirei & None \\
\hline ALK & & &
\end{tabular}

ALK, anaplastic lymphoma kinase.

and pathological specimens were fixed in formalin and paraffin-embedded. Both types of specimen were stained, as described in a previous report [16], in addition to ALK immunohistochemical staining of pathological specimens, which was performed using the intercalated antibody-enhanced polymer (iAEP) method [17].

\section{KIT mutation analysis}

The DNA was extracted from pathological specimens. Exons 11 and 17 of the KIT gene were amplified by PCR and used for direct sequencing [18].

\section{Fluorescent in-situ hybridization (FISH) examination of ALK}

To explore $A L K$ gene rearrangements, fluorescent in-situ hybridization (FISH) was performed using a Vysis ALK Break Apart FISH Probe kit (Abbott Molecular, Des Plaines, IL, USA) [19]. Briefly, unstained sections (4 $\mu \mathrm{m}$ thick) were subjected to hybridization according to the manufacturer's protocol. $A L K$ rearrangement was considered present when over $15 \%$ of the tumor cells displayed orange and green hybrid signals or an orange signal alone.

\section{Clinical history}

Our patient was a 31-year-old woman initially admitted to another clinic because of painful urination and subsequently transferred to our hospital for further examination. First, we performed a cytological study of her urine and a cystoscopic examination. The cytological study did not yield any specific findings, but cystoscopy detected a submucosal tumor lying beneath the normal mucosa (Figure 1A). Computed tomography and magnetic resonance imaging identified a mass $4.5 \mathrm{~cm}$ in diameter in the right lateral wall of the urinary bladder (Figure 1B,C). Transurethral resection of the bladder tumor (TUR-Bt) was performed to obtain a diagnosis. Spindle cells were collected during TUR-Bt, but they did not yield any diagnostic information because of heat denaturation.

We surgically resected the mass (Figure 2), which was located in the muscular layer of the urinary bladder, and was thus not contiguous with the mucosa. Imprint cytology was performed during resection (Figure 3A) and revealed numerous spindle cells with an abundance of cytoplasm and low nuclear atypia, admixed with infiltrating lymphocytes. Immunocytochemically, the spindle cells were negative for smooth muscle actin and desmin, but an anti-KIT antibody yielded a positive reaction (Figure 3B). However, the cells were also positive for ALK (Figure 3C). Histologically, a spindle cell tumor that was immunohistochemically positive for both KIT and ALK was also identified (Figure 4A-C). The fact that the nuclear atypia was of low grade and that a

Table 2 Antibodies used in immunostaining in immunohistological analyses.

\begin{tabular}{|c|c|c|c|c|}
\hline Antigen & Clone & Dilution & Source & Pretreatment \\
\hline SMA & $1 \mathrm{~A} 4$ & Prediluted & Nichirei & None \\
\hline Desmin & D33 & Prediluted & Nichirei & Microwave (10 min) \\
\hline Pan-cytokeratin & AE1/AE3 & Prediluted & Nichirei & Protease \\
\hline KIT & Polyclonal & $1: 25$ & DAKO & Microwave (10 min) \\
\hline ALK & $5 \mathrm{~A} 4$ & $1: 50$ & Nichirei & Boiling $(30 \mathrm{~min})^{*}$ \\
\hline PDGFR & Polyclonal & $1: 50$ & Santa Cruz & Boiling (60 min) \\
\hline DOG1 & SP31 & $1: 50$ & Nichirei & Boiling (60 min) \\
\hline $\lg G$ & EPR4421 & $1: 50$ & Epitomics & Boiling (30 min) \\
\hline lgG4 & HP6025 & $1: 50$ & Nichirei & Boiling (60 min) \\
\hline
\end{tabular}

* The iAEP method was required to obtain the signals. ALK, anaplastic lymphoma kinase; IgG, immunoglobulin G; PDGFR, platelet-derived growth factor receptor. 


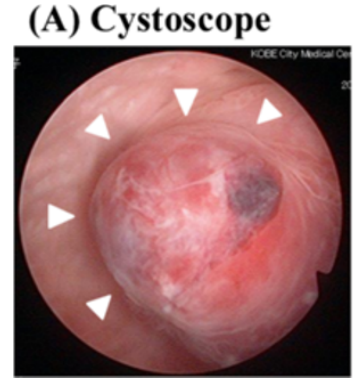

(B) CT

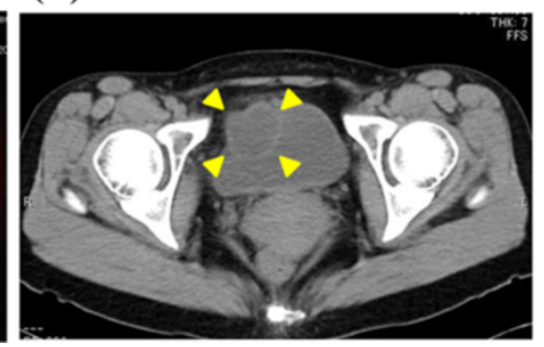

(C) MRI

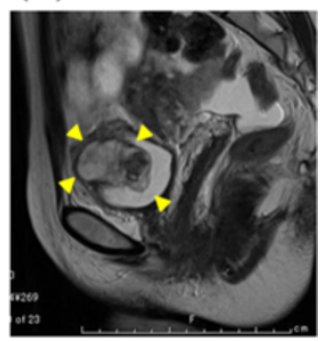

Figure 1 Cystoscopy, computed tomography, and magnetic resonance imaging findings. (A) Cystoscopy, (B) computed tomography, and (C) magnetic resonance imaging. White and yellow arrowheads indicate the submucosal tumor in the urinary bladder.

malignant component was lacking allowed us to rule out sarcomatoid cancer. We also excluded leiomyosarcoma and rhabdomyosarcoma because the tumor was negative for smooth muscle actin and desmin. In addition, staining for IgG and IgG4 indicated that the tumor was not an IgG4-related inflammatory pseudotumor, because IgG4-positive cells were very rare. A GIST was considered in differential diagnosis. We found no mutation in the KIT gene. The tumor cell cytoplasm stained weakly for KIT, which is unusual (but not unknown) for GIST tumors $[11,12]$. In addition, the cells were negative for other GIST markers (that is, PDGFR $\alpha$ and DOG1) $[14,15]$; therefore, we ruled out GIST. To evaluate the $A L K$ gene status, we performed FISH analysis using the Vysis $A L K$ Break Apart FISH Probe kit and found that approximately $20 \%$ of the signals indicated $A L K$ gene rearrangement (Figure 4D). Thus, we diagnosed the tumor as an IMT.

Our patient is alive and well, without recurrence, 3 years after resection.

\section{Discussion}

Most submucosal tumors in the wall of the urinary bladder are spindle cell tumors [20,21]. The spindle cell tumor in our patient expressed ALK. To the best of our knowledge, only one previous report examined the ALK status of GISTs and found that such tumors were ALK-negative [22]. However, more evidence is required to rule out a GIST, even if a spindle cell tumor is positive for ALK. $A L K$ rearrangement is associated with the pathogenesis of various malignancies, including anaplastic large-cell lymphoma, nonsmall cell lung cancer, and neuroblastoma [23]. In addition, $A L K$ rearrangement, associated with an altered enzyme expression level, is detected in approximately half of IMTs [4-7]. In the current case, we found that a significant proportion of $A L K$ genes were split (Figure 4D).

Morphological discrimination between IMT and GIST was nearly impossible in the present case, but we found that cytological examination was useful in this context. It was feasible to stain cytological specimens for ALK, and no pretreatment was required. However, we had to use a sophisticated method (iAEP method [19]) to stain the histological specimens (Table 1). Thus, cytological analysis using ALK immunostaining might be useful in differentiating an IMT from a GIST.

A variety of spindle cell tumors exhibit KIT positivity, including mesothelioma [24], leiomyosarcoma [24], clear cell

\section{(A) Halved}

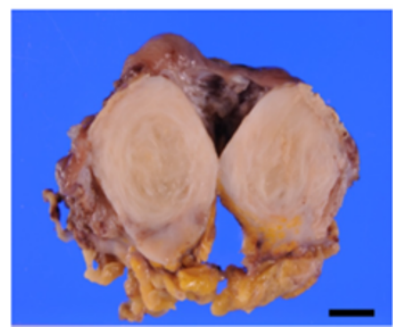

\section{(B) Sliced}

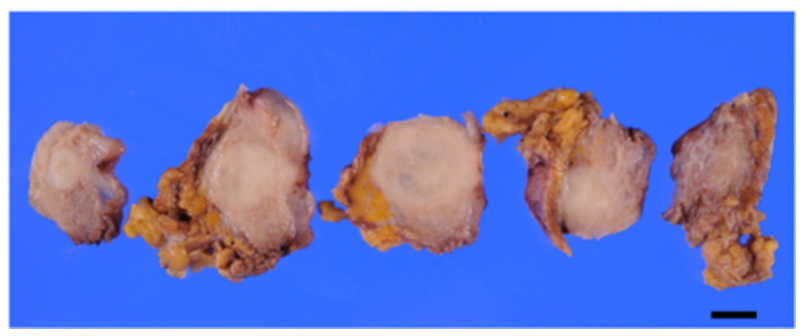

Figure 2 Macroscopic findings. (A) Halved specimens. (B) Sliced specimens. Bar, $1 \mathrm{~cm}$. 

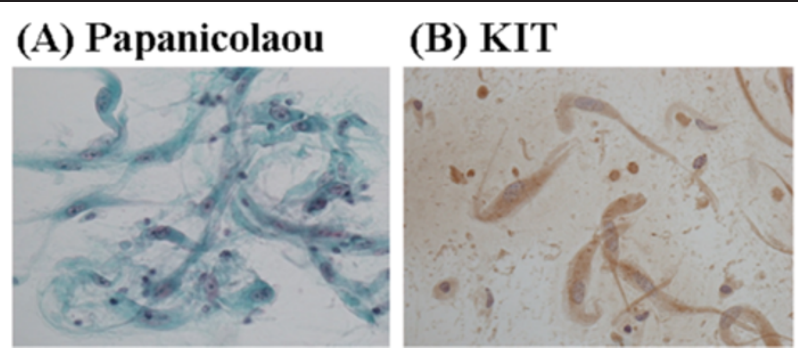

(C) ALK

staining using a monoclonal antibody purchased from Nichirei. All photographs were obtained at $400 \times$ magnification.

sarcoma [24], rhabdomyosarcoma [24], synovial sarcoma [24], angiomyolipoma [25,26], bladder urothelial carcinoma [24,27], and malignant melanoma [27]. Therefore, KIT immunopositivity alone cannot differentially diagnose a GIST among spindle cell tumors. In this case, the KIT staining pattern and the lack of PDGFR $\alpha$ and DOG1 immunoreactivity suggested that a GIST was unlikely.

Eventually, we diagnosed the tumor as a KIT-positive IMT. Such tumors are rare, with only two cases reported in the English-language literature [2]. Interestingly, both tumors were in the urinary bladder [2]. Therefore, KIT positivity alone might not be adequate to diagnose a GIST, especially if the tumor is in the urinary bladder.

\section{Conclusions}

A possibility of IMT should be included in the differential diagnosis of KIT-positive spindle cell tumors, especially those in the urinary bladder. Molecular exploration of $A L K$ rearrangements and KIT mutations may be required to diagnose KIT-positive spindle cell tumors.

\section{Consent}

Our patient kindly provided written informed consent for publication of this case report and the accompanying images.

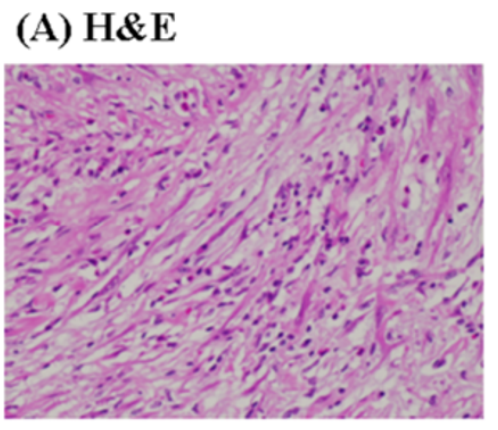

\section{(C) ALK (IHC)}

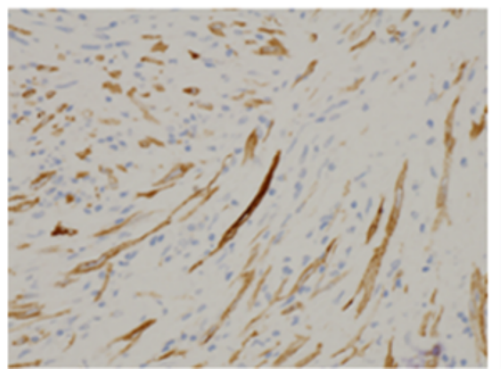

(B) KIT

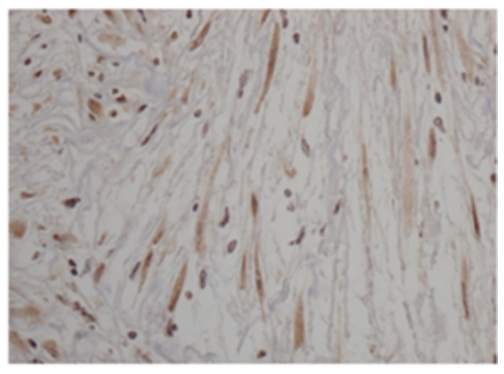

(D) ALK (FISH)

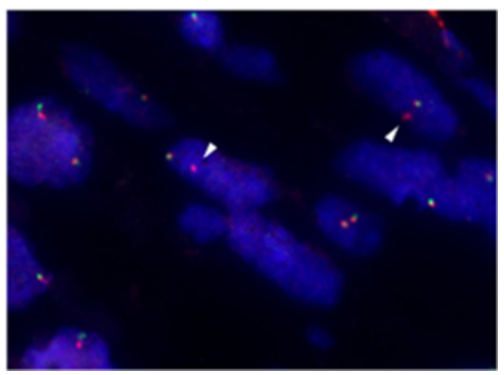

Figure 4 Histological findings. (A) H \& E staining. (B) KIT staining using a rabbit polyclonal antibody purchased from DAKO. (C) ALK staining using a monoclonal antibody purchased from Nichirei. (D) FISH analysis using the Vysis ALK Break Apart FISH Probe kit. White arrowheads indicate signals positive for ALK gene rearrangements. All photographs were obtained at 200x magnification. 


\section{Abbreviations}

ALK: anaplastic lymphoma kinase; FISH: fluorescent in-situ hybridization; GIST: gastrointestinal stromal tumor; H \& E: hematoxylin and eosin; IAEP: intercalated antibody-enhanced polymer; lgG: immunoglobulin G; IMT: inflammatory myofibroblastic tumor; PCR: polymerase chain reaction; PDGFRa: platelet-derived growth factor receptor a; TUR-Bt: transurethral resection of bladder tumor.

\section{Competing interests}

The authors declare that they have no competing interests.

\section{Authors' contributions}

$\mathrm{TRK}, \mathrm{SH}, \mathrm{HH}$, and EK conceived and designed the study. $\mathrm{NY}$ and $\mathrm{MH}$ performed the immunocytochemical and immunohistochemical assays. AF performed the FISH analysis. SH screened for KIT mutations. TI and IN collected the clinical data. TRK, NY, and EK assembled the data. TRK and $\mathrm{HH}$ wrote the manuscript. All authors approved the final manuscript.

\section{Acknowledgement}

This study was supported by grants from the Ministry of Education, Culture, Sports, Science and Technology of Japan.

\section{Author details}

'Department of Diagnostic Pathology, Kyoto University Hospital, Sakyo-ku, Kyoto 606-8507, Japan. 'Department of Pathology and Laboratory Medicine, Kobe City Medical Center West Hospital, Kobe, Hyogo 653-0013, Japan. ${ }^{3}$ Department of Urology, Kobe City Medical Center West Hospital, Kobe, Hyogo 653-0013, Japan. ${ }^{4}$ Department of Surgical Pathology, Hyogo College of Medicine, Nishinomiya, Hyogo 663-8501, Japan.

Received: 30 August 2013 Accepted: 12 June 2014 Published: 18 June 2014

\section{References}

1. Kovach SJ, Fischer AC, Katzman PJ, Salloum RM, Ettinghausen SE, Madeb R, Koniaris LG: Inflammatory myofibroblastic tumors. J Surg Oncol 2006, 94:385-391.

2. Montgomery EA, Shuster DD, Burkart AL, Esteban JM, Sgrignoli A, Elwood L, Vaughn DJ, Griffin CA, Epstein Jl: Inflammatory myofibroblastic tumors of the urinary tract: a clinicopathologic study of 46 cases, including a malignant example inflammatory fibrosarcoma and a subset associated with high-grade urothelial carcinoma. Am J Surg Pathol 2006, 30:1502-1512.

3. Sukov WR, Cheville JC, Carlson AW, Shearer BM, Piatigorsky EJ, Grogg KL, Sebo TJ, Sinnwell JP, Ketterling RP: Utility of ALK-1 protein expression and $A L K$ rearrangements in distinguishing inflammatory myofibroblastic tumor from malignant spindle cell lesions of the urinary bladder. Mod Pathol 2007, 20:592-603.

4. Lawrence B, Perez-Atayde A, Hibbard MK, Rubin BP, Dal Cin P, Pinkus $J$, Pinkus GS, Xiao S, Yi ES, Fletcher CD, Fletcher JA: TPM3-ALK and TPM4-ALK oncogenes in inflammatory myofibroblastic tumors. Am J Pathol 2000, 157:377-384.

5. Cessna MH, Zhou H, Sanger WG, Perkins SL, Tripp S, Pickering D, Daines C, Coffin CM: Expression of ALK1 and p80 in inflammatory myofibroblastic tumor and its mesenchymal mimics: a study of 135 cases. Mod Pathol 2002, 15:931-938.

6. Li XQ, Hisaoka M, Shi DR, Zhu XZ, Hashimoto H: Expression of anaplastic lymphoma kinase in soft tissue tumors: an immunohistochemical and molecular study of 249 cases. Hum Pathol 2004, 35:711-721.

7. Coffin CM, Hornick JL, Fletcher CD: Inflammatory myofibroblastic tumor: comparison of clinicopathologic, histologic, and immunohistochemical features including ALK expression in atypical and aggressive cases. Am J Surg Pathol 2007, 31:509-520.

8. Hirota S, Isozaki K: Pathology of gastrointestinal stromal tumors. Pathol Int 2006, 56:1-9.

9. Lasota J, Carlson JA, Miettinen M: Spindle cell tumor of urinary bladder serosa with phenotypic and genotypic features of gastrointestinal stromal tumor. Arch Pathol Lab Med 2000, 124:894-897.

10. Mekni A, Chelly I, Azzouz H, Ben Ghorbel I, Bellil S, Haouet S, Kchir N, Zitouna $M$, Bellil K: Extragastrointestinal stromal tumor of the urinary wall bladder: case report and review of the literature. Pathologica 2008, 100:173-175.

11. Hirota S, Isozaki K, Moriyama Y, Hashimoto K, Nishida T, Ishiguro S, Kawano K, Hanada M, Kurata A, Takeda M, Muhammad Tunio G, Matsuzawa Y, Kanakura Y, Shinomura Y, Kitamura Y: Gain-of-function mutations of c-kit in human gastrointestinal stromal tumors. Science 1998, 279:577-580.

12. Théou N, Tabone S, Saffroy R, Le Cesne A, Julié C, Cortez A, Lavergne-Slove A, Debuire B, Lemoine A, Emile JF: High expression of both mutant and wild-type alleles of c-kit in gastrointestinal stromal tumors. Biochim Biophys Acta 2004, 1688:250-256.

13. Kitamura Y, Hirota S: Oncogenic protein tyrosine kinases. Cell Mol Life Sci 2004, 61:2924-2931.

14. Hirota S, Ohashi A, Nishida T, Isozaki K, Kinoshita K, Shinomura Y, Kitamura Y: Gain-of-function mutations of platelet-derived growth factor receptor a gene in gastrointestinal stromal tumors. Gastroenterology 2003, 125:660-667.

15. West RB, Corless $C L$, Chen $X$, Rubin BP, Subramanian S, Montgomery K, Zhu S, Ball CA, Nielsen TO, Patel R, Goldblum JR, Brown PO, Heinrich MC, van de Rijn M: The novel marker, DOG1, is expressed ubiquitously in gastrointestinal stromal tumors irrespective of KIT or PDGFRA mutation status. Am J Pathol 2004, 165:107-113.

16. Kataoka TR, Fujimoto M, Moriyoshi K, Koyanagi I, Ueshima C, Kono F, Tsuruyama T, Okayama Y, Ra C, Haga H: PD-1 regulates the growth of human mastocytosis cells. Allergol Int 2013, 62:99-104.

17. Takeuchi K, Choi YL, Togashi Y, Soda M, Hatano S, Inamura K, Takada S, Ueno T, Yamashita Y, Satoh Y, Okumura S, Nakagawa K, Ishikawa Y, Mano H: KIF5B-ALK, a novel fusion oncokinase identified by an immunohistochemistry-based diagnostic system for ALK-positive lung cancer. Clin Cancer Res 2009, 15:3143-3149.

18. Hirota S, Nishida T, Isozaki K, Taniguchi M, Nakamura J, Okazaki T, Kitamura $Y$ : Gain-of-function mutation at the extracellular domain of KIT in gastrointestinal stromal tumours. J Pathol 2001, 193:505-510.

19. Takeuchi K, Soda M, Togashi Y, Sugawara E, Hatano S, Asaka R, Okumura S, Nakagawa K, Mano H, Ishikawa Y: Pulmonary inflammatory myofibroblastic tumor expressing a novel fusion, PPFIBP1-ALK: reappraisal of anti-ALK immunohistochemistry as a tool for novel ALK fusion identification. Clin Cancer Res 2011, 17:3341-3348.

20. Lott S, Lopez-Beltran A, Maclennan GT, Montironi R, Cheng L: Soft tissue tumors of the urinary bladder, Part I: myofibroblastic proliferations, benign neoplasms, and tumors of uncertain malignant potential. Hum Pathol 2007, 38:807-823.

21. Lott S, Lopez-Beltran A, Montironi R, MacLennan GT, Cheng L: Soft tissue tumors of the urinary bladder Part II: malignant neoplasms. Hum Pathol 2007, 38:963-977.

22. Cook JR, Dehner LP, Collins MH, Ma Z, Morris SW, Coffin CM, Hill DA: Anaplastic lymphoma kinase (ALK) expression in the inflammatory myofibroblastic tumor: a comparative immunohistochemical study. Am J Surg Pathol 2001, 25:1364-1371.

23. Pulford K, Morris SW, Mason DY: Anaplastic lymphoma kinase proteins and malignancy. Curr Opin Hematol 2001, 8:231-236.

24. Arber DA, Tamayo R, Weiss LM: Paraffin section detection of the c-kit gene product (CD117) in human tissues: value in the diagnosis of mast cell disorders. Hum Pathol 1998, 29:498-504.

25. Miliaras D, Karasavvidou F, Papanikolaou A, Sioutopoulou D: KIT expression in fetal, normal adult, and neoplastic renal tissues. J Clin Pathol 2004, 57:463-466

26. Makhlouf HR, Remotti HE, Ishak KG: Expression of KIT (CD117) in angiomyolipoma. Am J Surg Pathol 2002, 26:493-497.

27. Espinosa I, Lee CH, Kim MK, Rouse BT, Subramanian S, Montgomery K, Varma S, Corless CL, Heinrich MC, Smith KS, Wang Z, Rubin B, Nielsen TO, Seitz RS, Ross DT, West RB, Cleary ML, van de Rijn M: A novel monoclonal antibody against DOG1 is a sensitive and specific marker for gastrointestinal stromal tumors. Am J Surg Pathol 2008, 32:210-218.

doi:10.1186/1477-7819-12-186

Cite this article as: Kataoka et al:: An inflammatory myofibroblastic tumor exhibiting immunoreactivity to KIT: a case report focusing on a diagnostic pitfall. World Journal of Surgical Oncology 2014 12:186. 